\title{
Remote Sensing of Sea Surface Temperatures for Aquaculture Planning in Northern Norway
}

\author{
JOS KÖGELER ${ }^{1}$ and SALVE DAHLE ${ }^{1}$
}

(Received 13 August 1990; accepted in revised form 4 March 1991)

\begin{abstract}
A major limitation for salmon (Salmo salar L.) farming in arctic environments is the low winter temperatures influencing the salmon's growth rates, mortality and quality. A detailed knowledge of the sea temperature variations in a region can help to avoid the establishment of fish farms in areas that are less suitable. In order to supply local fish farmers and planning authorities with such information, a satellite survey of sea surface temperatures in a late winter situation was conducted in northern Norway. Landsat Thematic Mapper data were calibrated with in situ measurements. The relationship between sea surface temperatures and other factors in the physical environment was visualized in a very comprehensive way. Temperature zones were found to be consistent with information in literature and of relevance to the fish farming industry. New, potentially suitable sites for fish farming could be indicated in many areas where no historical data were available.
\end{abstract}

Key words: remote sensing, sea surface temperatures, aquaculture planning, northern Norway

RÉSUMÉ. Un des principaux obstacles à l'élevage du saumon (Salmo salar L.) dans un environnement arctique est la basse température hivernale, qui influe sur le taux de croissance du saumon ainsi que sur sa mortalité et sa qualité. Une connaissance détaillée des variations de la température de la mer dans une région donnée peut aider à éviter l'établissement de fermes piscicoles dans des zones moins favorables. Dans le but de fournir ce genre d'information aux pisciculteurs et aux autorités chargées de la planification, on a effectué en Norvège septentrionale un relevé par satellite des températures de la surface de la mer à la fin de l'hiver. Les données obtenues avec l'appareil de cartographie thématique Landsat ont été calibrées avec les mesures sur le site. La relation entre les températures de la surface marine et d'autres facteurs de l'environnement physique a été exprimée sous une forme visuelle très complète. On a trouvé que les zones de température correspondaient bien à l'information apparaissant dans les documents écrits, et qu'elles présentaient un intérêt pour l'industrie piscicole. On a pu d'autre part trouver, dans bien des zones sur lesquelles nous n'avons pas actuellement de données historiques, de nouveaux sites potentiels propices à la pisciculture.

Mots clés: télédétection, températures de la surface marine, planification de l'aquaculture, Norvège septentrionale

Traduit pour le journal par Nésida Loyer.

\section{INTRODUCTION}

Atlantic salmon (Salmo salar L. 1758) has optimal growth at temperatures between 10 and $18^{\circ} \mathrm{C}$. The lower temperature tolerance limit is $-0.5^{\circ} \mathrm{C}$. Growth rates rapidly decrease below temperatures of $5^{\circ} \mathrm{C}$ (Gjedrem, 1986). The daily growth rate is approximately $0.2 \%$ at $4^{\circ} \mathrm{C}$ and between 0.1 and $0.02 \%$ at temperatures below $2^{\circ} \mathrm{C}$ (Akvaforsk, pers. comm. 1989). Low annual temperatures and long periods of extreme cold are also known to reduce salmon's resistance to fish diseases (Haastein et al., 1989). This generally leads to higher mortality rates and a reduced quality of the salmon produced in the farm.

Salmon farming is a rapidly expanding industry in Norway. Production of Atlantic salmon has increased from less than 7000 tons in 1979 to more than 120000 tons in 1989 (Fish Farmers Sales Organization, pers. comm. 1990). The export value generated by this industry surpasses that of the traditional fishing industry. (Its first-hand value in 1989 was approximately US\$550 million.) The Norwegian Fish Farmers Organization estimates that approximately 18000 people work in aquaculture and related industries (K. Hernes, pers. comm. 1990).

Fish farms were initially concentrated in sheltered sites in the southwestern boreal parts of Norway, where average winter temperatures are favourable for salmon growth. Farming of salmon and other species in the subarctic and arctic parts of mainland Norway has, however, also proved to be profitable. In recent years, environmental considerations and socio-economic policies have been taken into account more strongly when issuing new farming licences. As a result, many new fish farms are now located in northern Norway.
More than 200 salmon farms and a smaller number of cod farms are in operation north of the Arctic Circle (Norwegian Ministry of Fisheries, 1989).

In northern Norway low temperature minimums are more likely to occur than farther south. However, average sea temperatures and the occurrence of low temperature extremes also vary from region to region within northern Norway. A detailed knowledge of local conditions can help to prevent the location of fish farms in less suitable areas and thus is of direct economic value to the industry. Based on salmon production and budgeting models, we estimate that for an average salmon farm in northern Norway, being situated in a zone with average temperatures of $2^{\circ} \mathrm{C}$, as opposed to $0^{\circ} \mathrm{C}$, during two to three winter months, salmon growth can be $15 \%$ higher in the same production period, thereby increasing the potential annual profit by at least half a million NOK (US\$90 000).

Data on temperature distribution in the coastal zones of northern Norway are scarce. Traditional methods for mapping of temperature variations cannot be used, as it is practically and economically difficult to perform simultaneous temperature measurements in sufficient numbers over large and inaccessible areas. A preliminary study showed that a combination of remote sensing and traditional in situ temperature measurements could provide reliable information on temperature zones at a relatively low cost (Holte and Kögeler, 1988).

The survey described in this paper was initiated by several planning agencies and fish farmers in northern Norway. The objective was to provide information on the geographical distribution of sea surface temperatures during cold winter periods to be able to find the best.locations for salmon rearing.

\footnotetext{
${ }^{1}$ AKVAPLAN A/S, Søndre Tollbugata. 3, N-9000 Tromsø, Norway

(C) The Arctic Institute of North America
} 


\section{MATERIAL AND METHODS}

\section{The Study Area}

The coastal zone being mapped stretches from $64-72^{\circ} \mathrm{N}$ and $10-30^{\circ} \mathrm{E}$ along the Norwegian coast. The area covers $\mathrm{ca}$. $130000 \mathrm{~km}^{2}$, with a coastline of about $20000 \mathrm{~km}$ (Fig. 1).

Sea temperatures along the Norwegian coast are influenced by two main currents, the Atlantic current (Gulf Stream) and the Norwegian coastal current. The Atlantic current enters the Norwegian Sea between the Shetland and Faroe islands, runs parallel to the Norwegian coast and divides into two branches north of the Lofoten Islands. One branch turns towards Spitsbergen, following the continental slope, and the other continues along the Norwegian coast entering the Barents Sea (Breen, 1980; Saelen, 1950).

In the Norwegian Sea, Atlantic water is dominant from the surface down to $600-700 \mathrm{~m}$. Atlantic water, with a salinity of $35 \%$ or more, has, even in winter, temperatures exceeding $6-7^{\circ} \mathrm{C}$. The Atlantic current gets gradually colder to the north, as it mixes with the colder coastal and bottom water of the Norwegian Sea (Saelen, 1950).

The coastal water of Norway is strongly influenced by the Norwegian coastal current. This is low-saline water originating from the Baltic Sea that mixes with Atlantic water and runoff from land as it flows towards the north. During winter, the coastal water north of the Arctic Circle can be considerably colder than the Atlantic water (Breen, 1980).

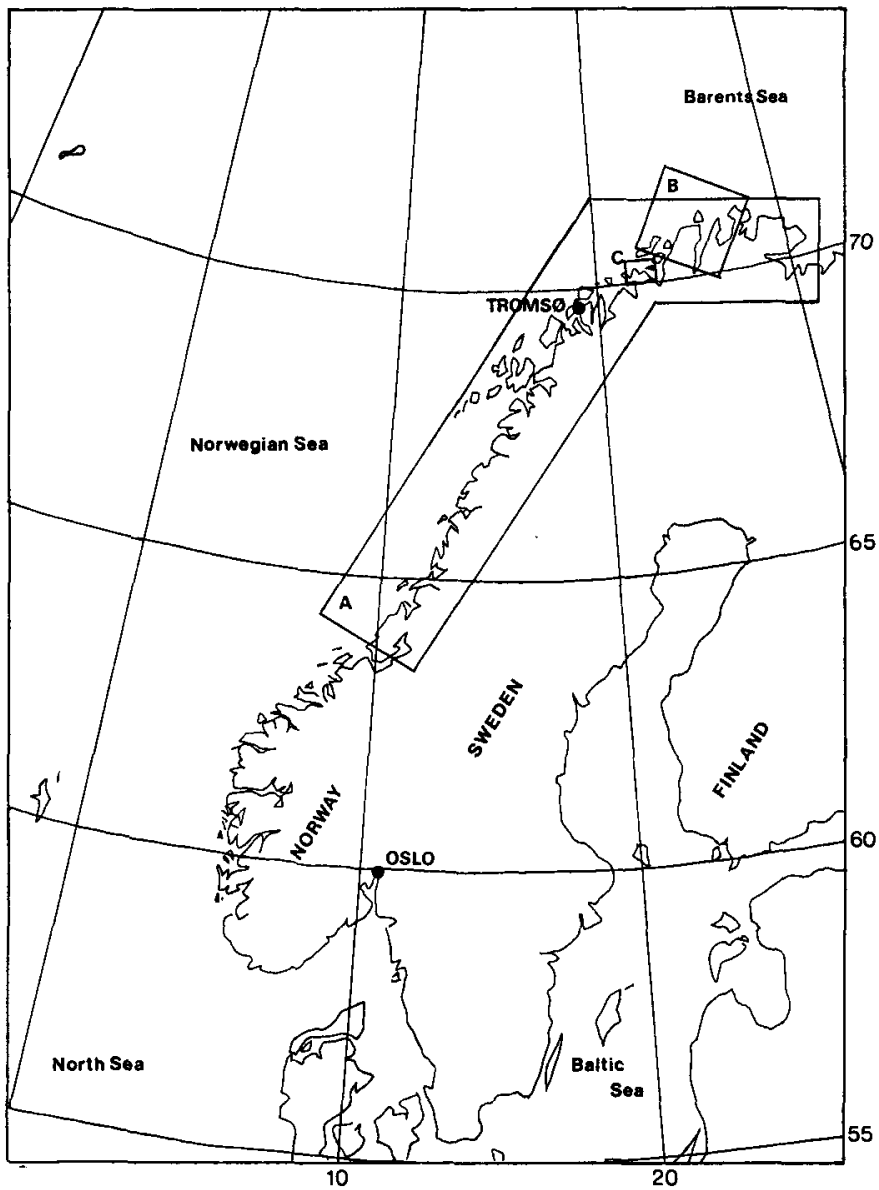

FIG. 1. Location of the study area in northern Norway (box A). The locations of the areas covered by the satellite images shown in Figures 3 and 4 are indicated by boxes $B$ and $C$.
The Barents Sea is relatively shallow, with an average depth of less than $300 \mathrm{~m}$. Temperatures are considerably lower than in the Norwegian Sea. The coldest water in the Barents Sea is found in the north and east (Breen, 1980).

In the survey area, the dominant surface wind direction in winter is off-land (Andresen, 1979). At the coast, the winds turn to the right and follow the coastline. Locally, winds are directed by topography, which to a high degree directs the prevailing winds blowing along the fjords (Andresen, 1979). The lowest air temperatures in the coastal area occur during the winter, when cold inland winds dominate for longer periods. Freshwater runoff is strongly influenced by snow accumulation during winter. Runoff is minimal from January to April, while maximum runoff is in June and July. The absence of a low-saline surface layer, combined with strong cooling of the surface water in winter, leads to an extensive vertical mixing of the water. By pulling surface water out of the fjords, winds can also set up temporary upwelling zones in the inner parts of the fjords, where warmer deep water is brought to the surface (Berge and Steen, 1985; Aure, 1979, 1983; Sundby, 1976; Nilsen and Hansen, 1980).

Because of these effects, areas with warmer deep water (i.e., fjords and coastal waters where no sills prevent interaction with Atlantic water) can have $1-3^{\circ} \mathrm{C}$ higher sea temperatures in winter than other areas (Aure, 1983; Sundby, 1984).

\section{Temperature Data Collected in situ}

Satellite images were selected using weather observation reports obtained from the Norwegian Meteorological Institute (DNMI) and Landsat Multi-Spectral Scanner (MSS) "quicklooks" (photographic presentations of satellite raw data acquired in the visible range of the solar spectrum). Detailed observation series on wind strength and direction, air and sea surface temperatures, humidity and precipitation for at least one month preceding satellite overpass, together with climatological data for the study area, were obtained from about 60 meteorological observation stations spread throughout the study area (DNMI, unpubl. reports).

In situ sea surface temperatures were measured within 6 hours from the Landsat overpass. Data were obtained from 120 fish farms and 4 lighthouses spread throughout the whole survey area, from 5 automatic measurement buoys and from coastal liners equipped with thermographs. From most of the in situ measurement sites daily temperature registration for several winters were also obtained.

Average monthly sea temperatures were collected for a number of years. These included meteorological observations made by DNMI and the Norwegian Institute for Marine Research since 1970 (Midttun, 1975), the University of Tromsø (Nordgård et al., 1982; Gulliksen et al., 1981) and thermograph recordings from the coastal express liners (Hurtigrute) dating back to 1936 and made available by the Norwegian Oceanographic Data Centre.

In situ temperature measurements were evaluated with respect to accuracy, reliability and local conditions. Unreliable data and data collected from areas possibly affected by clouds or freshwater runoff were not used in the calibration procedures. For each Landsat full scene $(185 \times 185 \mathrm{~km})$, an average of 10-15 in situ measurements could be used for calibration purposes. Calibration data for scenes acquired from the same satellite pass were grouped together. 


\section{Satellite Imagery and Processing System}

The survey area has a very complex and differentiated topography. In order to obtain reliable satellite data over areas with narrow fjords, sounds, inlets, small islands and extensive skerries, a sensor with high spatial resolution had to be chosen. For this reason the Landsat Thematic Mapper (TM) instrument, which has a $120 \mathrm{~m}$ spatial resolution in the thermal channel, was used in this survey.

Most spectral bands in the Landsat TM instrument have 16 sensors, each with a ground field view (GFV) of $30 \mathrm{~m}$. The thermal band (band 6), however, has only 4 sensors, each with a GFV of $120 \mathrm{~m}$. In order to make band 6 images overlap with images from other spectral bands, each thermal pixel is usually duplicated three times in both sample and line direction. This means that pure pixels, i.e., pixels with information not contaminated by temperatures over land areas, can be found in waters wider than $120 \mathrm{~m}$ only. Consequently, one can only be certain to find pure pixels over waters wider than $240 \mathrm{~m}$.

Satellite data were selected from the coldest months in recent years: March and April 1987 and March 1988. Landsat-5 TM computer-compatible tapes (CCT) were ordered from the European Space Agency (ESA) Earthnet Station in Sweden and processed at Tromsø Satellite Station (TSS) in Norway. Data processing was performed on an interactive image processor (International Imaging Systems, system 600) running on a uVAX II host computer.

Landsat TM images contain noise in the form of periodic striping across the data sets. These stripes mainly result from inaccurate sensor calibration. This effect is especially disturbing in band 6 images taken over water. The radiometric information contents in those images have a lower dynamic range when compared to imagery over land. Several algorithms have been developed in order to enhance image information content (Srinivasan et al., 1988). We used two methods - histogram modification, which is a simple gain and bias model, and 2-D Power Spectral Filtering, a Fourier transformation-based method.

We found histogram modification to be best suited, mainly because this method does not significantly modify the resultant pixel values. The duplicated samples and lines in band 6 were removed prior to processing. The image data were modified in such a way that the global histograms for each sensor were matched precisely with a suitable reference. The destriped image was restored to its original size by pixel duplication and then multiplied with a mask derived from TM band 4 .

The resultant image, showing only information over areas with open water, was compared with in situ temperature measurements. Correlation coefficients and regression equations between pixel values and temperature measurements were calculated for each image. A colour scale based on the regression equation was designed to make imagery from different dates and regions comparable. After the band 6 image had been colour coded, it was combined with a black and white image from band 4. This made it possible to delineate ice-covered waters and see land topography. Finally the images were geometrically corrected.

\section{RESULTS AND DISCUSSION}

As thermal infrared is emitted from the very surface, temperature registrations derived by remote sensing must be evaluated with great care when there is reason to assume that the water is stratified. In those cases, no relation can be expected between sea surface temperatures and the temperatures found in the water under the surface. (Salmon generally stay at least $2 \mathrm{~m}$ under the surface.) The water surface is generally stratified shortly after precipitation or solar warming and in areas influenced by freshwater runoff. The imagery was acquired around $10 \mathrm{a} . \mathrm{m}$. (GMT). In March and April, however, the sun angle in northern Norway is still low and solar radiation will not have influenced sea surface temperatures yet. Also, no precipitation was recorded during the days previous to the satellite passover.

In the coldest months of the year (February, March and April), sea surface temperatures in most Norwegian arctic fjords are representative for temperatures down to a depth of more than $75 \mathrm{~m}$ (see Saelen, 1950; Gulliksen et al., 1981; Eilertsen et al., 1981; Nordgård et al., 1982).

In situ temperatures measured in the upper $3 \mathrm{~m}$ ranged from -0.5 to $5^{\circ} \mathrm{C}$. Pixel values in the raw data varied from 69 to 92 (out of a scale of 0-255). Correlation coefficients for the correspondence between satellite pixel values and in situ sea surface temperatures and calculated for groups of consecutive images (acquired from the same day) were higher than 0.9 for each TM scene. Regression equations were different for each date, indicating differences in atmospheric attenuation. Figure 2 shows in situ measurements and the regression equation $\left(R^{2}=0.90, N=17\right)$ calculated for the image shown in Figure 3.

The maps resulting from this survey show temperatures as they were when the satellite passed over. As weather conditions usually are similar during cold periods (offshore winds), it is expected that the maps show the distribution of temperature zones as they usually occur in cold periods. It is not possible to predict with certainty the extreme temperatures for a given location.

Figure 3 shows the sea surface temperatures for the northernmost region covered by our survey as they were recorded 11 April 1987. The general trend is as to be expected, with the highest temperatures away from the coast and gradually decreasing temperatures closer to the mainland. The warmest water, $3-4^{\circ} \mathrm{C}$ (shown in yellow), is found farthest to the west, where the influence from Atlantic water is strongest. Most

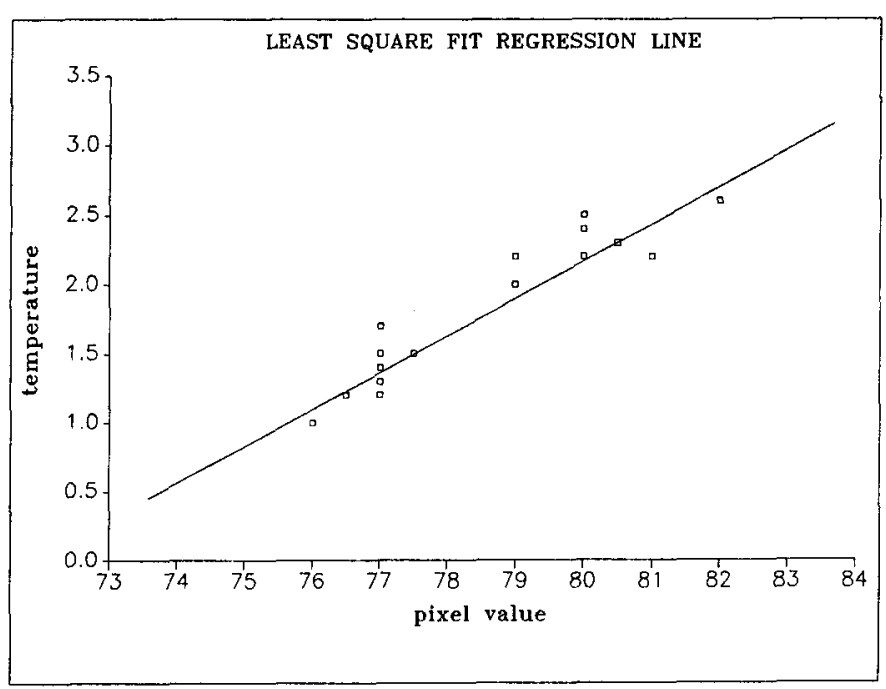

FIG. 2. Regression equation for the image in Figure 3. Correlation between in situ measurements and pixel values $R=0.95$. 


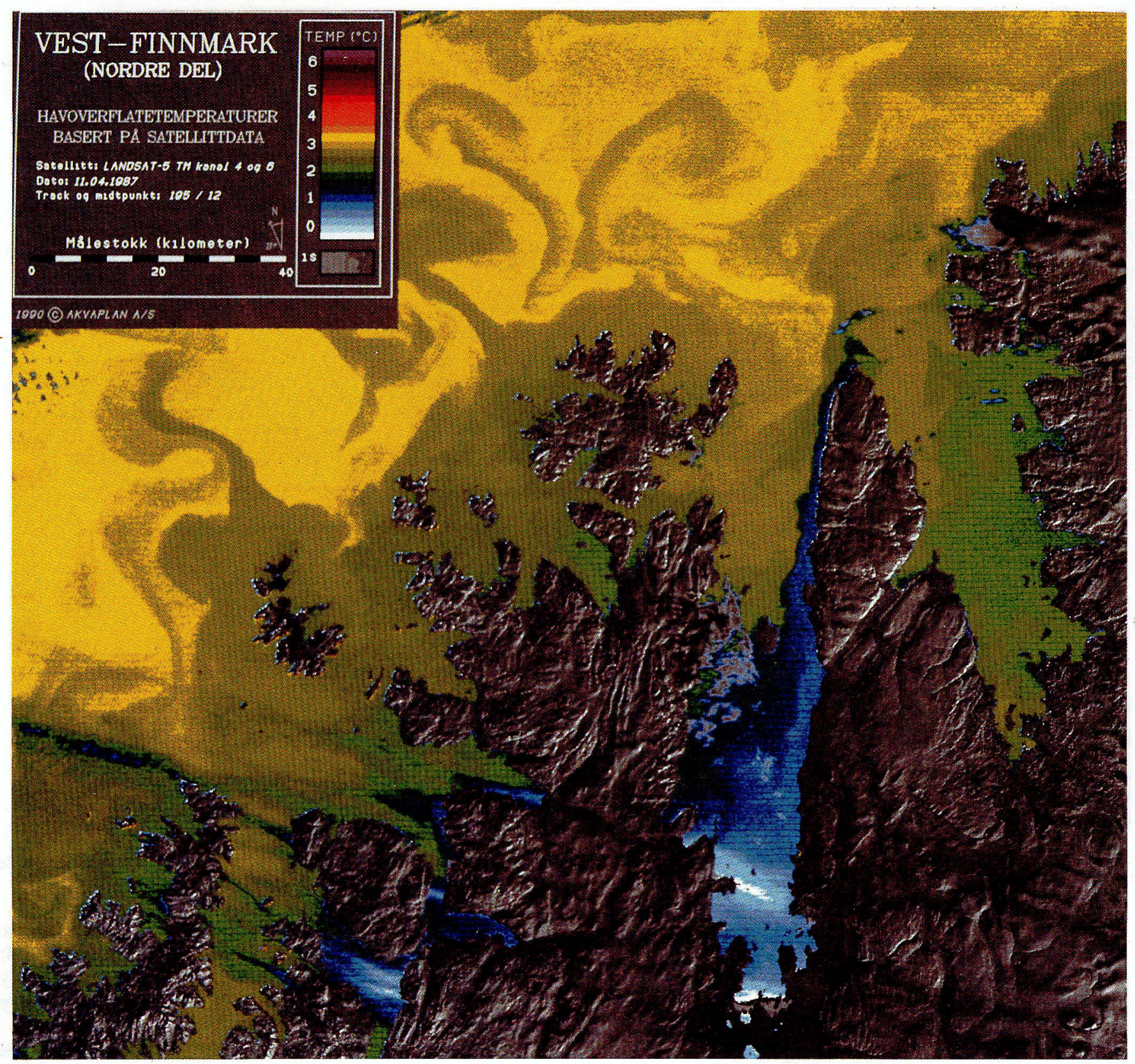

FIG. 3. Sea surface temperatures in the coastal zone of West-Finnmark. The North Cape is on the island in the top middle. Data are from Landsat (TM), 11 April 1987. (Original map scale 1:400 000. Temperature scale, orientation and scale bar are shown in the image.)

of the coastal water has a surface temperature of about $2^{\circ} \mathrm{C}$ (green). The image clearly shows the eddies formed along the front between the Atlantic current and the Norwegian coastal current. The coldest fjord of the Norwegian mainland is shown in the central part of the image. Here the sea surface has temperatures of $0-1^{\circ} \mathrm{C}$ (blue) and even temperatures below zero (light blue). The inner parts of the fjord are covered with ice. These low temperatures are probably due to the combined effects of sills with a depth of $160 \mathrm{~m}$ at the mouth of the fjord, which prevent warmer deep water from entering the fjord basin, and water masses with subzero temperatures and ice that originate from a large river discharging at the bottom of the fjord.

Also seen in Figure 3 are the cold out-going currents. These currents are clearly affected by the Coriolis Force. They flow out of the fjord at the right-hand side of the fjord (east), while in-flowing warmer water keeps closer to the western side of the fjord.

Figure 4 shows the surface temperatures in an area just south of the area depicted in Figure 3. The fjords in this area are exposed to the arctic winter, and only supplies of warm deep water can keep the surface temperatures above $2^{\circ} \mathrm{C}$. The relationship between winter temperatures in a fjord and its topography is clearly demonstrated. North of the mainland, depths are between 300 and $500 \mathrm{~m}$ (see Fig. 5). Through vertical circulation, warmer high-saline water is brought to the surface, so that this water keeps a temperature over $3^{\circ} \mathrm{C}$. The fjord farthest to the west has sills with depths of 50 and $90 \mathrm{~m}$ and is very cold $\left(0-1^{\circ} \mathrm{C}\right)$. The fjord in the centre of the image is warmer $\left(c a .2^{\circ} \mathrm{C}\right)$. This fjord has a sill depth of more than $200 \mathrm{~m}$, which allows for the inflow of warmer deep water. There are no major rivers in either of these fjords. The long, 


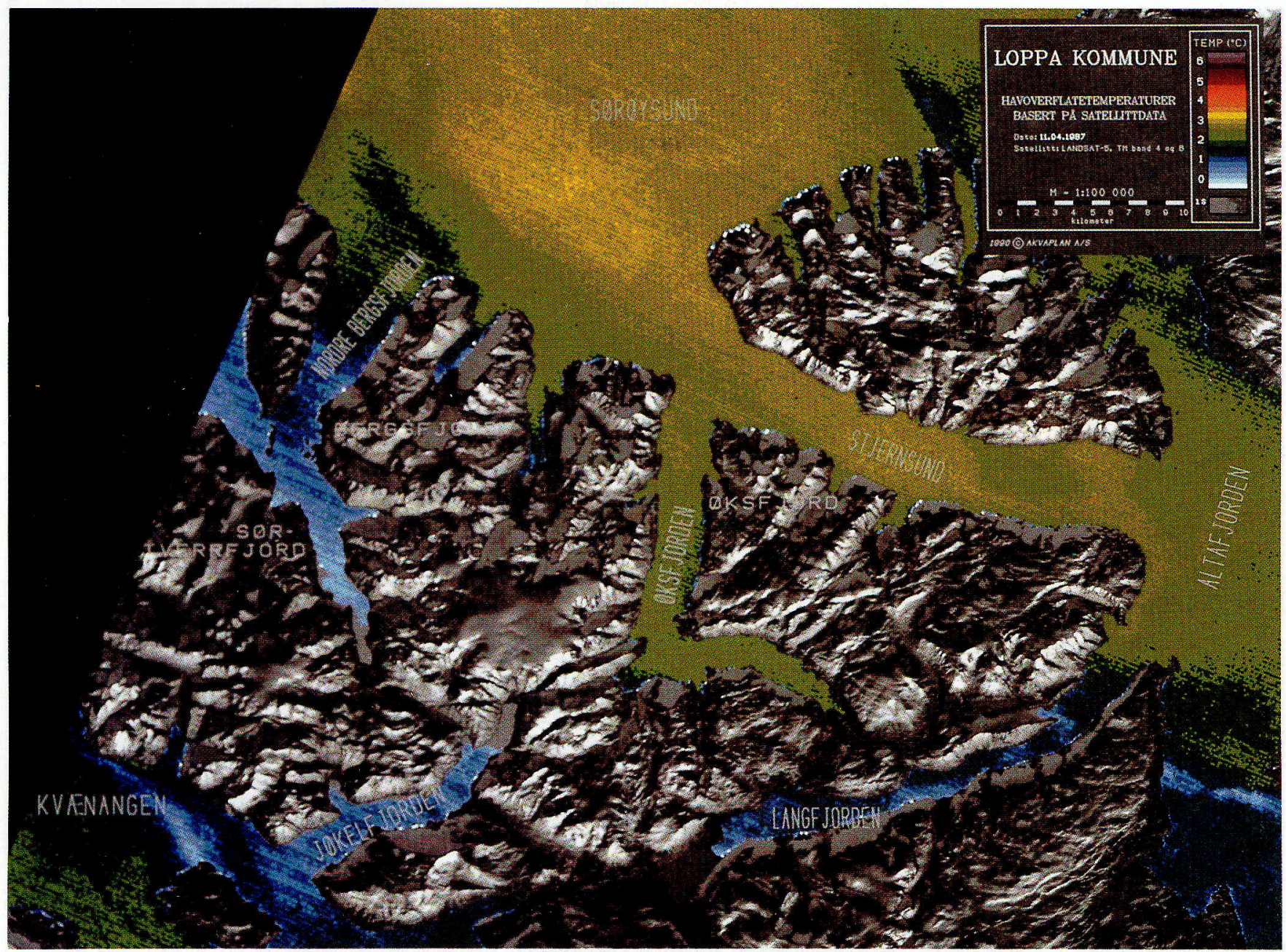

FIG. 4. The sea surface temperatures in the county of Loppa (Finnmark, northern Norway). Data from Landsat (TM), 11 April 1987. (Original map scale 1:100 000. Temperature scale and $\mathrm{km}$ bar are shown in the image. North is oriented upwards.)

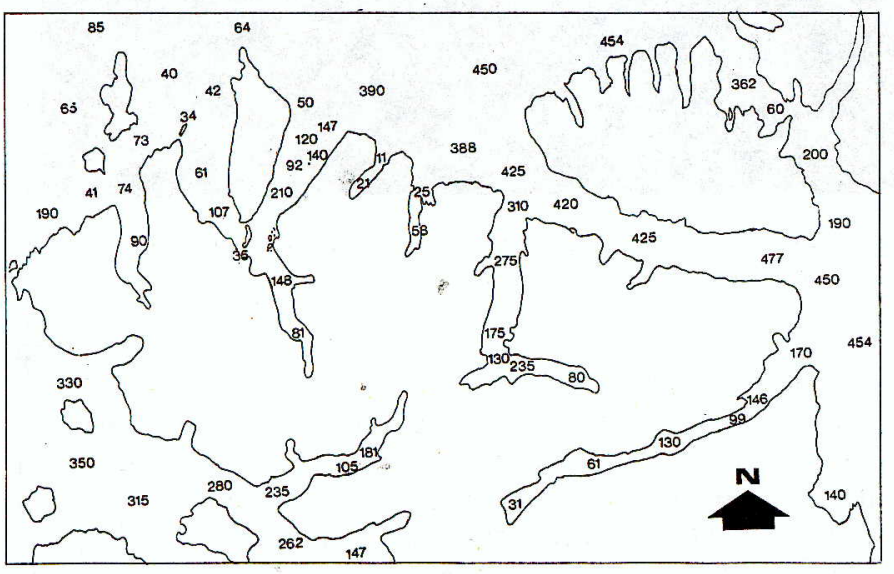

FIG. 5. Depth chart for the area depicted in Figure 4.

narrow fjord farther to the southeast has no obvious sills but is relatively shallow and therefore not influenced by warm deep water from adjacent fjords. The other fjords in the southern part of the image are possibly influenced by freshwater discharge from two large hydro-electric power plants.
The results of this survey were found to be in accordance with previous research (Aure, 1979, 1983; Sundby, 1984; Øvreeide, 1983). The survey showed that in areas strongly affected by Coriolis Forces and sills temperatures can vary significantly over short distances.

Through this study, knowledge of sea surface temperatures not only improved, but it was also visualized in a very comprehensive way. New potentially suitable sites for fish farming could be suggested in many areas where no historical data were available.

Some fish farms have used the sea surface temperatures generated through this study and moved their farms to other sites, where they hope to have increased growth and reduced fish mortality. We suggest that a salmon farmer operating a type of shifting cultivation with summer and winter sites could optimize the average annual temperatures for his operations and thereby obtain better salmon growth.

\section{ACKNOWLEDGEMENTS}

The project is part of a larger program for remote sensing in the coastal zones. This program was developed in cooperation with the LENKA-working group (LENKA: Suitability Evaluation of the Norwegian Coast for Aquaculture). The project was financially supported by the District Council for North-Norway and the Rural Development Board. 
We wish to thank the staff at Tromsø Satellite Station and Einar Grønas for helpful suggestions during image processing. We are also grateful to all the fish farmers and institutes that supplied us with in situ measurements.

\section{REFERENCES}

ANDRESEN, L. 1979. Monthly and annual frequencies of concurrent wind forces and wind directions in northern Norway and the Arctic for the period 1961-75. Climatological Summaries for Norway. Oslo: Det Norske Meteorologiske Institutt.

AURE, J. 1979. Akvakultur i Øst Finnmark. Kartlegging av mulighetene for fiskeoppdrett og langtidslagring av sei. Fisken og Havet Series B 1979(9):1-94.

1983. Akvakultur i Troms. Kartlegging av mulighetene for fiskeoppdrett og langtidslagring av sei. Fiske og Havet Series B 1983(1):1-92.

BERGE, F.S., and STEEN, J.E. 1985. Temperaturforhold langs kysten av nord Norge. Trondheim: Rapport Norwegian Hydrotechnical Laboratories. $190 \mathrm{p}$.

BREEN, O. 1980. Oseanografi. Grunntrekk fra generell havlaere og litt hydrografi fra havområder av saerlig interesse for norske fiskerier. Oslo: Fabritius Forlagshus.

EILERTSEN, H.C., FALK-PETERSEN, S., HOPKINS, C.C.E., and TANDE, K. 1981. Ecological investigations on the plankton community of Balsfjorden, northern Norway. Program for the project, study area, topography and physical environment. Sarsia 66:25-34.

GJEDREM, T. 1986. Fiskeoppdrett med framtid. Gjerdum, T., ed. Oslo: Landbruksforlaget. $328 \mathrm{p}$.
GULLIKSEN, B, NORDGẢRD, O., NORMANN, U. and PETTERSEN, F. 1981. Havmiljødata fra nordnorske fjorder i 1980. Tromura 14. Tromsø: University of Tromsø.

HẢSTEIN, T., LUNDEN, T., and POPPE, T.T. 1989. De viktigste sykdommer hos oppdrettsfisk. Norsk Veterinaer Tidsskrift 101(6):389-408.

HOLTE, B., and KÖGELER, J.W. 1988. Forslag til akvakuturplanlegging i Lurøy Kommune. Report AKVAPLAN A/S, S. Tollbugt. 3, N9000 Tromsø, Norway. $142 \mathrm{p}$.

MIDTTUN, L. 1975. Observasjonsserier av overflatetemperaturer og saltholdighet i norske kystfarvann 1936-70. Fisken og Havet Series B. 1975(5),

NILSEN, J., and HANSEN, E. 1980. Temperatur og saltholdighet i en rekke norske fjorder den kalde vinteren 1978/79. Report. Norwegian Hydrotechnical Laboratories, N7034 Trondheim, Norway.

NORDGẢRD, O, NORMAN, U., and PETTERSEN, F. 1982. Havmiljødata fra nordnorske fjorder i 1981. Tromura 38. Tromsø: University of Tromsø.

NORWEGIAN MINISTRY OF FISHERIES. 1989. Register over Fiskeoppdrettsanlegg. Bergen.

ØVREEIDE, A. 1983. Kartlegging av lokaliteter for akvakulturanlegg i Nordland. Report. Bodø: Nordlandsforskning. 83 p.

SAELEN. O.H. 1950. The hydrography of some fjords in northern Norway. Tromsø Museum Årshefte 70(1):1-93.

SRINIVASAN, R., CANNON, M., and WHITE, J. 1988. Landsat data destriping using power spectral filtering. Optical Engineering 27(11):939-943.

SUNDBY, S. 1976. Akvakultur i Vest Finnmark. Lokalisering av velegnede steder. Fisken og Havet Series B (10):1-43.

1984. Influence of the bottom topography on the circulation at the continental shelf of northern Norway. Fiskeridirektoratets Skrifter Serie Havundersøkelser 17:501-519. 